\title{
The Use of Extrinsic Evidence to Interpret Real Property Conveyances: A Suggested Limitation
}

The early common law often required compliance with specific formalities to make transactions effective. ${ }^{1}$ As the law has developed, however, dependence on form has substantially diminished. ${ }^{2}$ In consequence, the sanctity of written instruments has also decreased. Following this general trend, the California courts now admit extrinsic evidence to interpret written documents under very liberal standards. This policy of broad admissibility is based on a recognition that written instruments frequently fail to reflect the intentions of the parties. This Note examines the expansion of the uses of extrinsic evidence in the field of real property transactions, concentrating on the California Supreme Court's decision in Beuhler v. Oregon-Washington Plywood Association. $^{3}$ It argues that in real property law the need to protect third parties who rely on the public record requires that the use of extrinsic evidence be carefully restricted.

The discussion proceeds in four parts. Part I describes Califorma's general rules governing the use of extrinsic evidence to interpret contracts, while part II examines these rules in the context of transactions in real property. Part III suggests that a different rule is needed when bona fide purcliasers are involved. Part IV reevaluates the rules on extrinsic evidence and property instruments in general in light of the recording acts-statutes virtually unique to real property.

I

ADMISSION OF EXTRINSIC EVIDENCE TO INTERPRET

WRITTEN CONTRACTS-IN GENERAL

The law can be a stubborn creature. It sometimes steadfastly clings to a well-worn rule long after that rule has been universally condemned by the commentators. The "plain meaning" rule is an excellent exainple of this plienomenon. Under that rule, a court may admit extrinsic evidence to interpret a written contract only when the instru-

1. See generally 1A A. CoRbin, CoNTracts $\S \S 240-41$ (1963); 6 R. POWELL, The LAW of Real Property $\ 879$ (1949) [hereinafter cited as Powell].

2. See generally Perillo, The Statute of Frauds in the Light of the Functions and Dysfunctions of Form, 43 FordhaM L. Rev. 39 (1974).

3. 17 Cal. 3d 520, 551 P.2d 1226, 131 Cal. Rptr. 394 (1976). 
ment is ambiguous on its face. ${ }^{4}$ This limitation on the admissibility of concededly relevant evidence is aimed at diminishing the danger of perjury and increasing commercial certainty, by permitting reliance on written instruments. ${ }^{5}$ The critics' attack las been primarily based on the inherent imprecision of written language. As Professor Corbin wrote:

[I]t can hardly be insisted on too often or too vigorously that language at its best is always a defective and uncertain instrument, that words do not defime themselves, that terms and sentences in a contract, a deed, or a will do not apply themselves to external objects and performances, that the meamings of such terms and sentences consist of the ideas that they induce in the mind of some individual person who uses or hears or reads them, and that seldom in a litigated case do the words of a contract convey one identical meaning to the two contracting parties or to third persons. ${ }^{6}$

It follows that since the ultimate object in interpreting a contract is to ascertain and effectuate what the parties intended, ${ }^{7}$ and since the words of the agreement can provide only a crude approximation of that intent, the court must soinetimes go beyond the agreement to determine its meaning.

Despite prolonged and vigorous attacks, some California courts adhered to the plain meaning rule until recently. ${ }^{8}$ In 1968 , the California

4. J. Calamari \& J. Perillo, Contracts $\$ 50$ (1970) thereinafter cited as Calamari \& Perillo]; 3 A. Corbin, Contracts $\$ 542$ (1960) [hereinafter cited as CorbiN]; 9 J. Wigmore, A TREATISE on the ANGlo-AMerican System of Evidence in TrIALS AT COMMON LAW $\$ 2461$, at 190 (3d ed. 1940) (hereinafter cited as Wiomore]. The "plain meaning" rule is closely related to, and sometimes considered a part of the parol evidence rule, which bars the use of extrinsic evidence to contradict or add to an integrated written contract. For varying formulations of the parol evidence rule, see

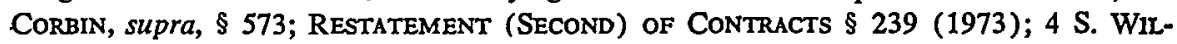
LisToN, ConTRACTs $\$ 631$ ( $3 \mathrm{~d}$ ed. 1957). Corbin stoutly asserts that "[t]he 'parol evidence rule' is not, and does not purport to be, a rule of interpretation or a rule as to the admission of evidence for the purpose of interpretation." CoRBIN, supra, §579. See Restatement (SeCOND) of Contracts \$ 239, Comment a (1973); Note, Chief Justice Traynor and the Parol Evidence Rule, 22 STAN. L. REv. 547, 556-57 (1970). In practice, however, the rules of interpretation and the parol evidence rule cannot be so sharply separated. Whether evidence really supplements or varies terms of a contract or instead merely interprets those terms is a fine and troublesome distinction. The characterization of the use of the evidence can be easily manipulated by a clever trial lawyer. See CaLaMari \& PenrLlo, supra, \$§ 50-51; Sweet, Contract Making and Parol Evidence: Diagnosis and Treatment of a Sick Rule, 53 CoRNELI L. REv. 1036, 1041-42 (1968); text accompanying notes 12-15 infra.

5. E. Morgan, Bastc Problems of Evidence 414 (4th ed. 1963) [hereinafter cited as MORGAN]; Wigmore, supra note 4, \$2462, at 192.

6. CoRbin, supra note $4, \S 536$. Corbin's concerns are echoed in Wrgmore, supra note 4, \$2462, at 192-93.

7. CoRBIN, supra note 4, § 572B (Supp. 1971).

8. E.g., Laux v. Freed, 53 Cal. 2d 512, 348 P.2d 873, 2 Cal. Rptr. 265 (1960); Wechsler v. Capitol Trailer Sales, Inc., 220 Cal. App. 2d 252, 33 Cal. Rptr. 680 (3d 
Supreme Court heeded the criticism. In Pacific Gas \& Electric Co. $v$. G. W. Thomas Drayage \& Rigging Co. $(P G \& E),{ }^{9}$ Chief Justice Traynor delivered an opinion which substantially liberalized California's rules concerning the use of extrinsic evidence to interpret written contracts. Relying on the difficulties in ascertaining the precise meaning of written words, the court held that the admissibility of extrinsic evidence should not be determined from the written instrument alone. Instead, the trial judge inust first examine all the credible evidence the parties offer to prove what they intended the contract to mean. The court must then determine whether, in the light of this evidence, the words of the contract are reasonably susceptible to either of the conflicting interpretations offered by the parties. If the words could fairly bear either meaning, then the extrinsic evidence is admissible to prove which interpretation was intended by the parties. ${ }^{10}$

Cases following PG\&E have generously defined both the kinds of extrinsic evidence that are sufficiently credible to be admitted and the types of interpretations to which an instrument is reasonably susceptible. For exaniple, the supreme court has held that testimony concerming negotiations that culminated in a written contract should be admitted to determine which interpretations a writing may fairly bear. ${ }^{11}$ The broad parameters of "reasonable susceptibility" are demonstrated

Dist. 1963). California law, however, was not entirely clear. Several courts of appeal decisions questioned the rule explicitly or implicitly. E.g., Schmidt v. Macco Constr. Co., 119 Cal. App. 2d 717, 260 P.2d 230 (1st Dist. 1953); Wells v. Wells, 74 Cal. App. 2d 449, 169 P.2d 23 (1st Dist. 1946). The supreme court added further complexity to the law with its statement in Barham v. Barham, 33 Cal. 2d 416, 423, 202 P.2d 289, 293 (1949) that "[w]here any doubt exists as to the purport of the parties' dealings as expressed in the wording of their contract, the court may look to the circumstances surrounding its execution . . . as well as to subsequent acts or declarations of the parties" (emphasis added). One writer has asserted that the law was so confused prior to 1968 that it amounted to no law at all. Note, Chief Justice Traynor and the Parol Evidence Rule, 22 STAN. L. REv. 547, 557 (1970).

9. 69 Cal. 2d 33, 442 P.2d 641,69 Cal. Rptr. 561 (1968).

10. Id. at 37-40, 442 P.2d at 644-46, 69 Cal. Rptr. at 564-66. This development in the law regarding admissibility of extrinsic evidence for purposes of interpretation followed shortly after au equally important development concerning the introduction of extrinsic evidence to modify or supplement written agreements. In Masterson v. Sine, 68 Cal. 2d 222, 436 P.2d 561, 65 Cal. Rptr. 545 (1968), Chief Justice Traynor, writing for the court, held that whether a contract is integrated need not be deternined from the face of the instrument. Rather, courts should admit evidence of collateral oral agreements if such evidence is credible.

11. Delta Dynamics, Inc. v. Arioto, 69 Cal. 2d 525, 446 P.2d 785, 72 Cal. Rptr. 785 (1968). This holding provoked a sharp dissent by Justice Mosk, who contended that the admission of such evidence would destroy the certainty of written contracts, and extend $P G \& E$ too far. Id. at 532,446 P.2d at 789-90, 72 Cal. Rptr. at 789-90. Justice Mosk's concerns resurfaced in his dissent in Beuhler. 17 Cal. $3 \mathrm{~d}$ at 530, $551 \mathrm{P.2d}$ at 1232,131 Cal. Rptr. at 400. 
by Diamond v. Insurance Co. of North America. ${ }^{12}$ A policy holder sued to recover the replacement cost of the insured property rather than its depreciated value. The replacement cost recovery feature had been added to the policy by an endorsement providing that replacement cost could not be recovered "unless and until the damaged property is actually repaired or replaced."13 The plaintiff property owner claimed that, properly interpreted, the endorseinent permitted hin to waive the requirement of replacement and still recover the replacement cost. The appeals court held that, although standing alone the language of the complaint was not reasonably susceptible to plaintiff's interpretation, the complaint merited a trial. The court stated that it could not anticipate (and indeed it is difficult to imagine) what evidence plaintiff might present in support of his interpretation. Nevertheless, it held that the denurrer to his complaint had been inproperly sustained and that the trial court should have heard whatever evidence the plaintiff might have to offer. ${ }^{14}$ Implicit in the disposition is the court's belief that under some set of facts the endorsement would be reasonably susceptible to plaintiff's interpretation. Thus, the Diamond decision virtually obliterates the distinction between interpretation and outright contradiction or variance. ${ }^{15}$ Not all courts of appeal have gone so far. ${ }^{16}$ But cases like Diamond illustrate the almost unlimited discretion that the $P G \& E$ rule grants to trial court judges.

II

\section{EXTRINSIC EVIDENCE AND INSTRUMENTS Conveying Real Property}

Although the pressure in favor of relaxing the standards governing the introduction of extrinsic evidence began in the context of coinmercial contracts, ${ }^{17}$ it has also affected the interpretation of writings that

12. 267 Cal. App. 2d 415, 72 Cal. Rptr. 862 (2d Dist. 1968).

13. Id. at $417,72 \mathrm{Cal}$. Rptr. at 863 . The endorsement also provided that the property owner "may elect first to make claim under this policy in accordance with its provisions, disregarding this endorsement . . . and the insured may make further claim for any additional liability brought about by the endorsement in accordance with its provisions . . . ." Id.

14. Id. at 419,72 Cal. Rptr. at $864-65$.

15. See Cochran v. Union Lumber Co., 26 Cal. App. 3d 423, 429, 102 Cal. Rptr. 632, 636 (1st Dist. 1972), which suggests that a reference to timber "now standing" might be reasonably susceptible to an interpretation that it actually referred to a time five years earlier.

16. See, e.g., American-Hawaiian S.S. Co. v. Home Savings \& Loan Ass'n, 38 Cal. App. 3d 73, 112 Cal. Rptr. 987 (2d Dist. 1974); People ex rel. Dep't of Parks \& Recreation v. West-A-Rama, Inc., 35 Cal. App. 3d 786, 111 Cal. Rptr. 197 (4th Dist. 1973).

17. See, e.g., Frigaliment Importing Co. v. B.N.S. Int'l Sales Corp., 190 F. Supp. 116 (S.D.N.Y. 1960), discussed in Corbin, The Interpretation of Words and the Parol Evidence Rule, 50 CORNELL L.Q. 161, 164-70 (1965). 
convey interests in real property. Real property law retains certain exceptions to the rule of broad admissibility, most of which are intended to protect bona fide purchasers. These exceptions suggest that where instruments convey interests in real property, concerns other than that of effecting the intentions of the parties must be considered.

\section{A. Prevailing Rule}

At common law, real property imstruments were traditionally construed in accord with special rules unique to the field. ${ }^{18}$ The dominant modern trend, however, is that writings conveying interests in real property are to be interpreted by the same standards as other contracts. The modern approach is apparent in Willard v. First Church of Christ, Scientist, ${ }^{19}$ where the supreme court rejected the common law rule that a deed could not reserve an interest in favor of a stranger to the deed. The court stated that: "[O]ur primary objective in construing a conveyance is to try to give effect to the intent of the grantor. ... In general, therefore, grants are to be imterpreted in the same ways as other contracts and not according to rigid feudal standards." ${ }^{20}$ In Continental Baking Co. v. $\mathrm{Katz}^{21}$ the court rehed on this principle as a basis for holding that extrinsic evidence could be used to interpret an ambiguous grant of an easement. The reasoning of both the Continental Baking and $P G \& E$ opinions has been liberally applied to instruments conveying interests in real property. In Murphy Slough Association v. Avila, ${ }^{22}$ the court construed a deed that unambiguously appeared to be a grant of a fee simple, and concluded that it conveyed only an easement. ${ }^{23}$ To find that the instrument was reasonably susceptible to this surprising interpretation, the court relied on the nominal consideration recited in the deed, ${ }^{24}$ the fact that the grantee was a reclamation district and the

18. See, e.g., 4 Tiffany, The LaW of ReAL Property 1 978-80 (3d ed. 1975).

19. 7 Cal. 3d 473, 498 P.2d 987, 102 Cal. Rptr. 739 (1972).

20. Id. at 476,498 P.2d at 989,102 Cal. Rptr. at 741.

21. 68 Cal. 2d 512, 521-22, 439 P.2d 889, 894, 67 Cal. Rptr. 761, 766 (1968). The Continental Baking case preceded the $P G \& E$ decision by two and one-half months. Because the court found the document ambiguous on its face, it did not address the problem of using extrinsic evidence to create ambiguities.

22. 27 Cal. App. 3d 649, 104 Cal. Rptr. 136 (5th Dist. 1972).

23. 1d. at 658, 104 Cal. Rptr. 143. The dced stated:

[t]he said parties of the first part . . grant, bargain and sell, convey and confirm unto the [grantee], all the certain lots, pieces and parcels of land .... Together with all and singular, the tenements, hereditaments and appurtenances thereunto belonging or in any wise appertaining and the reversion and reversions, remainder and remainders, rents, issues and profits thereof. Id. at 651-52, 104 Cal. Rptr. at 139 (emphasis is the court's).

24. Rehance on the recitation of consideration in a deed is extremely troubling because such recitals often bear little resemblance to the actual consideration paid. 
subsequent actions of the grantor. ${ }^{25}$ In Guntert $v$. City of Stockton ${ }^{20}$ the lessor city was permitted to terminate its lease whenever it received a bona fide offer to buy the leasehold property. A clause in the agreement expressly reserved for the lessor "sole discretion" to determine whether an offer to buy was, in fact, bona fide. ${ }^{27}$ Basing its interpretation on the prior negotiations of the parties, the court held that this clause imposed on the lessor a duty to demonstrate that the evaluation of any purchase offer met a standard of reasonableness. The court concluded that reasonableness rather than mere good faith must have been the intended standard because the lessee had sought assurances against arbitrary action and would not have completely capitulated..$^{28}$ These cases illustrate that the dominant trend in interpreting real property instruments is to permit wide use of extrinsic evidence. ${ }^{20}$ This development, however, has not yet been consistently extended to all transactions in real property. Those exceptions that remain provide an important insight into the kinds of concerns that ought to limit the use of extrinsic evidence to interpret property conveyances.

\section{Delivery of Deeds}

The cases most at variance with the $P G \& E$ rule are those inter-

25. Id. at 655-58, 104 Cal. Rptr. at 141-43.

26. 43 Cal. App. 3d 203, 117 Cal. Rptr. 601 (3d Dist. 1974).

27. The clause stated:

Lessor [City of Stockton] shall have the right to terminate said lease ... when the City Council of the Lessor has received and agreed to accept a bona fide offer or proposal to develop the demised premises ... . . The determination as to the validity of said offer or proposal and the economic feasibility and the ability to adequately finance such development shall be at the sole discretiou of said City Council.

Id. at 207 n.2, 117 Cal, Rptr. at 603 n.2.

28. Id. at 211-13, 117 Cal. Rptr. at 606-08.

29. A sharp contrast to such cases is provided by Safwenberg v. Marquez, $50 \mathrm{Cal}$. App. 3d 301, 123 Cal. Rptr. 405 (2d Dist. 1975). Safwenberg illustrates the reluctance that some courts feel in admitting extrinsic evidence to interpret deeds. In Safwenberg the plaintiff's predecessors, her parents, owned land adjoining an abandoned street. They conveyed that land to one of the defendants and the predecessors of the other defendant by deeds describing the land only by block and lot number with reference to a recorded map. Both grantors told both grantees that the conveyance did not include any interest in the abandoned street; in the 25 years between the conveyance and the litigation the grantees acted as if they owned no interest in the street area. The court ruled, however, that the grantees had been granted an interest in the street area. This was due to the general presumption that where property is conveyed by reference to a tract map, the grantee takes to the center of adjoining streets shown on the map unless the deed shows a contrary intention. The court excluded extrinsic evidence of a contrary intention because the deed itself was not ambiguous, id. at 309, $123 \mathrm{Cal}$. Rptr. at 410, ignoring the more liberal Continental Baking and PG\&E rules. The court's decision may rest on a deternination that the public policy of avoiding the ownership of land in strips should outweigh the policy of effecting the parties' intentions, where those intentions are not clearly expressed in the deed. Id. at 306, 123 Cal. Rptr. at 408. 
preting section 1056 of the California Civil Code. Section 1056 provides that when delivery of a deed is made directly to a grantee, the delivery is either absolute or totally ineffectual. ${ }^{30}$ If the grantor intends to irrevocably convey any imterest in property, whether the interest is contingent or vested, possessory or future, the deed takes effect as its written provisions designate, discharged of any conditions on which the delivery was made. ${ }^{31}$ Most decisions under section 1056 concern traditional conditions precedent. The most common condition discharged is that a deed should not take effect until the grantor's death. ${ }^{32}$ Other cases, however, have construed "condition" to encompass limitations that are more appropriately classed under the rubric of interpretation. It has been held that limits on the duration of an interest ${ }^{33}$ and restrictions on the use of the property granted ${ }^{34}$ are conditions discharged by section 1056 . Unless implicitly overruled by Continental Baking and $P G \& E$, these interpretations of section 1056 will place occasional restraints on the receipt of extrinsic evidence.

The reason given to support the strict interpretation of section 1056 suggests an important distinction between instruments affecting real property and other contracts:

The foregoing principle nay appear to be harsh and in some cases it certainly is contrary to the wishes and intent of the parties. The reason for the rule appears to be the reluctance of the law to permit or encourage the conditional manual delivery of a deed to a grantee which appears on its face to be valid in all respects and thus open the way to fraud and misunderstanding in regard to third parties who have no knowledge of the conditions imposed aliunde..$^{35}$

The cases arising under section 1056 thus illustrate one situation where the policy of effectuating the intentions of the parties is subordinated to that of protecting third parties.

\section{The Riley Decision}

A less obvious and more recent departure from the principles of

30. CAL. CTv. Code $\$ 1056$ (West 1954).

31. Id.; Ivancovich v. Sullivan, 149 Cal. App. 2d 160, 307 P.2d 989 (1st Dist. 1957); Blackledge v. McIntosh, 85 Cal. App. 475, 259 P. 770 (1st Dist. 1927).

32. E.g., Bias v. Reed, 169 Cal. 33, 145 P. 516 (1914); Shaver v. Canfield, 21 Cal. App. 2d 734, 70 P.2d 507 (3d Dist. 1937); Elliott v. Merchant's Bank \& Trust Co., 21 Cal. App. 536, 132 P. 280 (2d Dist. 1913).

33. Blackledge v. McIntosh, 85 Cal. App. 475, 259 P. 770 (1st Dist. 1927) (life estate vs. fee simple).

34. California Trust Co. v. Hughes, 111 Cal. App. 2d 717, 245 P.2d 374 (2d Dist. 1952) (property to be used only in effectuating divorce settlement); Hebert v. Miller, 94 Cal. App. 2d 211, 210 P.2d 251 (3d Dist. 1949); Security-First Nat'l Bank v. Leatart, 75 Cal. App. 2d 211, 170 P.2d 687 (2d Dist. 1946).

35. Ivancovich v. Sullivan, 149 Cal. App. 2d 160, 166, 307 P.2d 989, $993-94$ (1st Dist. 1957). 
the PG\&E decision is the supreme court's opinion in Riley v. Bear Creek Planning Committee, ${ }^{36}$ where the court upheld the traditional rule of Werner $v$. Graham ${ }^{37}$ governing the creation of equitable servitudes. The Werner rule requires that to create an equitable servitude the restrictions must be contained within the deed in language that both describes which parcels are to be benefitted by the restrictions and states that such parcels will also be bound. ${ }^{38}$ The Riley court based its holding on the policies underlying the Statute of Frauds: (1) providing more reliable written evidence in order to avoid the possibility of perjury and maximize the certainty of land titles; ${ }^{39}$ (2) forcing the parties to clarify their agreement in order to put it into written forma cautionary function, ${ }^{40}$ and (3) bringing any restrictions that inight be created withim the operation of the recording acts, thereby eliminat$\mathrm{mg}$ the difficult problems of proof that arise in litigating the issue of actual notice. ${ }^{41}$

By focusing on the Statute of Frauds as a basis for the Werner rule, the court attempted to distinguish its recent cases hiberalizing the rules permitting the introduction of extrinsic evidence for purposes of interpretation. Indeed the court reiterated the primciples of Masterson v. Sine and Continental Baking, ${ }^{42}$ and emphasized that its holding in Riley should not be interpreted as inipinging on them. ${ }^{43}$

The court's distimction between the policies underlying the Statute of Frauds and the extrimsic evidence rule, and thus between the two sets of cases, is not convincing. The court did not discuss any of the policies that underly the rules excluding extrinsic evidence. Instead the majority merely described the rule's effect: "'Extrimsic evidence is excluded because it cannot serve to prove what the agreement was, this being determined as a matter of law to be the writing itself.' "44 Had the court gone on to analyze the purposes behind the exclusion of extrinsic evidence, it would have been compelled to acknowledge that the parol evidence rule serves policies very similar to those advanced

36. 17 Cal. 3d 500, 551 P.2d 1213, 131 Cal. Rptr. 381 (1976).

37. 181 Cal. 174, 183 P. 945 (1919).

38. Id. at $183,183 \mathrm{P}$. at 949 .

39. 17 Cal. 3d at 510, 551 P.2d at 1220, 131 Cal. Rptr. at 388 .

40. Id. at 511. 551 P.2d at 1220-21, 131 Cal. Rptr. at 388-89.

41. Id. at 511-12, 551 P.2d at 1221-22, 131 Cal. Rptr. at 389-90. The court also noted that in California the interests created by equitable servitudes are considered real property. Id. at $510,551 \mathrm{P} .2 \mathrm{~d}$ at $1221,131 \mathrm{Cal}$. Rptr. at 389. This statement suggests that the creation of equitable servitudes is explicitly governed by the section of the Statute of Frauds that requires a writing to create interests in land. CaL. Crv. Proc. Code $\S 1971$ (West 1955); CAL. CTV. Code \$ 1091 (West 1954).

42. 17 Cal. 3d at 508, 551 P.2d at 1219, 131 Cal. Rptr. at 387.

43. Id. at 512 n.7, 551 P.2d at 1222 n.7, 131 Cal. Rptr. at 390 n.7.

44. Id. at 509, $551 \mathrm{P} .2 \mathrm{~d}$ at $1219,131 \mathrm{Cal}$. Rptr. at 387 (quoting $1 \mathrm{~B}$. WrrkiN, SUMMaRY OF CALIFORNIA LAW, CoNTRACTs, § 204 (8th ed. 1973)). 
by the Riley court in support of the Werner rule. The policy of maximizing certainty by permitting only written evidence is frequently cited by commentators as a reason for excluding extrinsic evidence for purposes of interpretation. ${ }^{45}$ If written evidence is a more reliable way to establish the existence of an agreement, it should also be a more reliable indication of what the parties intended their agreement to mean. The cautionary function served by reducing an agreement to writing is reinforced by excluding extrimsic evidence to interpret the writing. If the parties are aware that the written agreement will constitute the sole legally bimding contract between them, they may well be imduced to take more care in articulating their agreement in that instrument. Finally, the exclusion of extrinsic evidence to interpret agreements tends to strengthen the protection given to bona fide purchasers ${ }^{4}$ - a result in accord with the Riley court's avowed policy. Thus, to the extent that the policies invoked to support the Werner rule are given general application, ${ }^{47}$ they undermine the wholesale importation of the $P G \& E$ rule for use in the interpretation of contracts conveying interests in real property.

\section{III}

The Recording Acts and the Use of Extrinsic EVIDENCE TO INTERPRET WRITINGS

The arguments in favor of relaxing the rules regulating the use of extrinsic evidence to interpret instruments rest on the premise that the primary goal of the court should be to ascertain and then enforce the intentions of the parties to the contract as of the time the contract was inade. ${ }^{48}$ When the parties to the contract are the only persons with legally recognized interests in its interpretation, this view of the court's function is appropriate. Because words do have variable meanings and because exceptions to the parol evidence rule have destroyed mucl1 of the rule's capacity to achieve certainty in commercial transactions, ${ }^{49}$ the exclusion of extrinsic evidence often results in the

45. E.g., MoRgan, supra note 5, at 414; Wigmore, supra note 4, § 2462, at 192.

46. See section III infra.

47. Cf. Note, Equitable Servitudes: Some New Reasons for an Old Rule, 65 CaLIF. L. REv. 438, 443-50 (1977) (suggesting that the policies articulated by the court are rather unclear but that other reasons specific to equitable servitudes do support the opinion).

48. E.g., Pacific Gas \& Elec. Co. v. G.W. Thomas Drayage \& Rigging Co., 69 Cal. 3d 33, 38, 442 P.2d 641, 644, 69 Cal. Rptr. 561, 564 (1968); CoRBIN, supra note 4, \$ 579; see notes 6-7 supra and accompanying text.

49. Morgan, supra note 5, at 414; Comment, The Parol Evidence Rule and Third Parties, 41 Fordham L. REv. 945, 950-51 (1973) [hereinafter cited as Comment, Parol Evidence]. 
triumph of form over substance and in frustration of the parties' intent. The broad rule of admission for original parties therefore seems sound.

In the realm of real property transactions, however, persons other than the original parties to the transaction are often both extremely interested in and affected by the legal consequences of an instrument conveying an interest in real property. Riley and the cases interpreting section 1056 recognize the importance of safeguarding the interests of third parties. More importantly, the legislature has also given these interests significant protection through the recording acts.

\section{A. The Statutory Mechanism}

The California recording acts establish a procedure for placing instruments affecting title to real property in a record to which the public has access. ${ }^{50}$ The purpose of such statutes is most frequently stated to be the protection of purchasers who honestly and reasonably believe that they are acquiring good title to a piece of land from prior conveyances that create inconsistent interests. ${ }^{51}$

Section 1214 of the Civil Code provides that any conveyance of real property is void as against a party who subsequently purchases or encumbers that property for a valuable consideration provided that the party purchases in good faith and first records that conveyance. ${ }^{62}$ Good faith requires the absence of any notice-actual, constructive or inquiry-of the conveyance. ${ }^{53}$ Actual notice is knowledge by purchasers of prior conveyances inconsistent with their own; inquiry notice is knowledge of circumstances that would lead a reasonable purchaser

50. Cal. Crv. Code $\S \S 1107,1213-18$ (West 1954); CAL. Gov'T Code $\$ \S 27201-$ 05, 27230-40, 27243-44, 27247-51, 27264-65, 27280-88, 27289-90, 27292-96, 27320-21, 27322-30, 27333-35 (West 1968); id. $\S \S 27206,27257,27288.1,27297,27321.5$ (West Supp. 1977).

51. Beach v. Faust, 2 Cal. 2d 290, 40 P.2d 822 (1935); Chamberlain v. Bell, 7 Cal. 292 (1857); City of Los Angeles v. Morgan, 105 Cal. App. 2d 726, 234 P.2d 319 (2d Dist. 1951). But see Anderson v. Willson, 48 Cal. App. 289, 191 P. 1016 (2d Dist. 1920). See also notes 102-106 infra and accompanying text.

52. CAL. Crv. Code $\$ 1214$ (West 1954). Conveyances are defined quite broadly as "every instrument in writing by which any estate or interest in real property is created, aliened, mortgaged or imcumbered, or by which the title to any real property may be affected, except wills." Id. $\$ 1215$. Conversely, bona fide purchasers are not protected against interests created by meaus other than conveyauces, such as interests derived froin adverse possession. Cross, Weaknesses of the Present Recording System, 47 IOWA L. REv. 245, 255-57 (1962).

53. See United States v. Certaim Parcels of Land, 85 F. Supp. 986 (S.D. Cal. 1949) (actual and inquiry notice); CAL. CIv. CODE $\$ 1213$ (West 1954) (constructive notice). See generally 5 Tiffany, The LAW of ReAL Property, \$ 1283-84 (3d ed. 1939); 3 B. Witkin, Summary of California Law, Real Property \& 157 (8th ed. 1973). This defmition brings section 1214 into consonance with section 1217, which gives effect to unrecorded instruments as between the parties and those with notice of such instruments. CAL. CTV. CODE $\$ 1217$ (West 1954). 
to inquire and, by a reasonable search, to discover the existence of an inconsistent interest. ${ }^{54}$ A prior recorded conveyance within the purchaser's chain of title gives constructive notice of the contents of the recorded instrument. ${ }^{55}$

The fact that a subsequent purchaser is charged with notice of the contents of all previously recorded instruments need not, however, imply that a purchaser is charged with notice of all possible interpretations of such imstruments. The $P G \& E$ rule may bind a party to the original agreement to an interpretation made possible primarily or only by the introduction of extrinsic evidence. ${ }^{56}$ The protection given by the recording statutes to subsequent purchasers against conveyances that are not contained in the record suggests that a similar limitation should be placed on the $P G \& E$ rule to protect them against the assertion of interpretations that are not obviously suggested by the record.

\section{B. The Beuhler Case}

The problen of what types of interpretations may be asserted against a bona fide purchaser arose recently in Beuhler $v$. OregonWashington Plywood Association..$^{57}$ In Beuhler the parties were contesting the interpretation of an agreenent creating a road easement executed in 1956 by the Beuhlers as grantors and Smith, Moores and Cloverdale Redwood Company as grantees. ${ }^{58}$ The agreement was made to settle a prior dispute over the extent of existing timber rights and easements for hauling the timber. The Beuhlers contended in the earher dispute that the grantees were perimitted only to cut lumber that was merchantable in 1908, the date of the original grant of timber rights and the road easement, that merchantability was to be determined by specified methods, that the easement could be used only to haul timber nained in the 1908 grant, that the road easeinent had been abused and that the grantees had forfeited their rights through undue delay. ${ }^{59}$

The agreement granted permanent easements in gross over specified roads "for any purposes reasonably related to the ownership, manageinent and exploitation of timber and forest products which from

54. Smith v. Yule, 31 Cal. 180 (1866), overruled on other grounds, Bell v. Pleasant, 145 Cal. 410, 414 (1904); 1 R. Patton \& C. Patton, Land Trtles $\$ 14$ at 74 (2d ed. 1957) [hereinafter cited as PATtON]. See notes 77-82 infra and accompanying text.

55. Renden v. Geneva Dev. Corp., 253 Cal. App. 2d 578, 61 Cal. Rptr. 463 (2d Dist. 1967); 5 TIFFANY, supra note 53, § 1293.

56. See text accompanying notes 9-10 supra.

57. 17 Cal. 3d 520, 551 P.2d 1226, 131 Cal. Rptr. 394 (1976).

58. Id. at 524, 551 P.2d at 1228-29, 131 Cal. Rptr. at 396-97.

59. Id. 
time to time may be owned or controlled by the owner or owners of said easements ...." ${ }^{\circ 0}$ The easements were assignable, but only to entities who controlled timber rights to at least one-third of the timber situated on designated parcels, all within a parcel of land known as the Garcia tract. ${ }^{81}$ The agreement was recorded in 1956. In 1962, the Oregon-Washington Plywood Corporation acquired the easement and substantially all the Garcia tract property. After Oregon-Washington began usimg the easement to haul timber harvested on lands outside the Garcia tract, the Beuhlers sued for declaratory rehef and for trespass. They contended that the easement should be interpreted to restrict use of the right of way to hauling timber cut from lands within the Garcia tract. The trial court granted summary judgment to Oregon-Washington, finding both that the language of the easement was completely clear-there were no territorial restrictions on the origin of the timber hauled-and that the current holder of the easement was a bona fide purchaser with no knowledge of any interpretation that would restrict the origin of the timber. ${ }^{62}$

The court of appeal reversed, and the supreme court upheld the court of appeal, adopting its opinion with some modifications. The supreme court used both the words of the imstrument and extrinsic evidence to interpret the agreement. It first suggested that the paragraph describing the extent of the use, which referred siniply to "timber . . . which from time to time may be owned or controlled," could be explained as a means of settling the previous controversy over dates of merchantability. ${ }^{63}$ It relied heavily on the limits on the assignability of the easement, finding that they suggested limits on its usage. ${ }^{64}$ Finally, the court seemed to rely on the statements of Beuhler and his attorney as to their understanding of the agreement at the time it was drafted. ${ }^{65}$ On the basis of this evidence, the court summarily held that the subsequent purchasers could not be protected as bona fide purchasers because the instrument's meaning was not clear. ${ }^{\theta 8}$

60. Id. at $526 \mathrm{n} .2,551$ P.2d at $1230 \mathrm{n} .2,131$ Cal. Rptr. at $398 \mathrm{n} .2$.

61. Id.

62. Id. at 525, 529, 551 P.2d at 1229, 1232, 131 Cal. Rptr. at 397, 400. Longview Fibre Company had purchased most of the property involved from Oregon-Washington in 1965, and at that time acquired an option to obtain the easement at a later time. Oregon-Washington conveyed the easement to Longview just prior to the granting of the summary judgment.

63. Id. at 527, 551 P.2d at 1231, 131 Cal. Rptr. at 399. See text accompanying note 59 supra.

64. Id. at 527-28, 551 P.2d at 1231, 131 Cal. Rptr. at 399.

65. The court held that the statements, which were contained in affidavits, should have been admitted, but failed to clearly indieate what significance it attributed to them. Id. at 528-29, 551 P.2d at 1231-32, 131 Cal. Rptr. at 399-400.

66. Id. at 529, 551 P.2d at 1232, 131 Cal. Rptr. at 400. 
The standard applied by the court to permit the admission of extrinsic evidence against a subsequent purchaser is difficult to ascertain, and once ascertained, is very troubling. The court initially stated a fairly stringent rule adopted from decisions of the Kentucky and Oregon Supreme Courts: ${ }^{67}$

When a 'conveyance in the chain of title under which a purchaser for value claims shows on its face it is so ambiguous as to leave room for reasonable differences of opinion as to what was granted' . . . 'the purchaser will be chargeable with notice of this ambiguity' ....68

Because this rule allows subsequent purchasers to rely on the record title, it provides substantial protection for bona fide purchasers, and still accommodates the interests of original parties against claims of unreasonable subsequent buyers. In its application of the rule, lowever, the court violated both the letter and the intent of the standard it purported to adopt.

First, under the stated rule the court should have scrutinized the words of the document alone. Instead, the court relied on extrinsic as well as intrinsic evidence to create an ambiguity in the agreement. The court used the earlier dispute over merchantability to explain away the clause of the instrument that specifically described the extent of the easement. The earlier controversy, liowever, involved not only a question of merchantability, but also a question of whether the easeinent could be used to haul timber harvested outside the original grant. ${ }^{69}$ Thus, the court's attempt to limit the significance of the extent clause by reference to the earlier disagreement is unpersuasive. In addition, the court may have given some credence to the testimony offered by the Beuhlers.

Second, it is doubtful that a fair reading of the document, with or without extrinsic evidence, could render it ambiguous. The court claimed that the limits on assignability could be read to restrict an entirely different aspect of the easement-its extent. Sucli a cross-referencing of the limitations is neither necessary nor reasonable. The court asserted that it could conceive of no explanation for the limita-

67. The question whether extrinsic evidence could be used against a bona fide purchaser had not previously been decided by the supreme court or the courts of appeal. The only California decision cited by the court in its brief discussion on the subsequent purchaser problem was Renden v. Geneva Dev. Corp., 253 Cal. App. 2d 578, 61 Cal. Rptr. 463 (2d Dist. 1967). Renden, however, dealt with the problem of whether a purchaser is charged with notice of the contents of documents that are not within the chain of title, but to which reference is made by instruments within the chain.

68. $17 \mathrm{Cal} .3 \mathrm{~d}$ at $529,551 \mathrm{P} .2 \mathrm{~d}$ at $1232,131 \mathrm{Cal}$. Rptr. at 400 (quoting Hudson \& Collins v. McGuire, 188 Ky. 712, 723-24, 223 S.W. 1101, 1105-06 (1920)).

69. See text accompanying note 59 supra. 
tions on assignability other than an intention to restrict the extent of the easement. ${ }^{70} \mathrm{~A}$ more obvious purpose of the limits on assignment, however, is to control the number and type of persons who could use the roads. ${ }^{71}$ Moreover, the fact that questions of extent were specifically addressed in a different section of the agreement negates any inference that the parties intended the assignment provisions to control this issue. Stretching the limits on assignability to embrace extent might have been reasonable were no other imterpretation possible. When a more logical interpretation is available, such a strained reading goes beyond determining whether the agreement was itself ambiguous, that is, whether it was reasonably susceptible on its face to the interpretation asserted by the Beuhlers. At best, it is an interpretation to which the document is possibly susceptible once great weight is given to extrinsic evidence. ${ }^{72}$ The reasoning of the Beuhler opinion thus abandons the test it purports to adopt. Instead, it applies the standard developed for parties to any ordinary commercial contract against parties otherwise entitled to the special protection mandated by the recording acts.

\section{General Treatment of Bona Fide Purchasers}

The tension between the rule as stated and the rule as applied in Beuhler suggests that the court did not fully consider the issues raised by the case. There is, therefore, a need for a detailed analysis of the interests at stake to determine whether the rule permitting the use of extrinsic evidence slould be different when bona fide purchasers are involved. A bona fide purchaser against whom another party asserts an unfavorable interpretation will commonly claim ignorance of the interpretation. If the interpretation is one which only extrinsic evidence establishes as reasonable, the third party is likely to lack actual knowledge. If the court nevertheless accepts the interpretation, the effect is to charge the purchaser with constructive notice (because the words being interpreted are of record) or inquiry notice (because the purcliaser should have learned of the interpretation). An exammation

70. 17 Cal. $3 d$ at 528, 551 P.2d at 1231, 131 Cal. Rptr. at 399. ing).

71. Id. at 532, 551 P.2d at 1233-34, 131 Cal. Rptr. at 401-02 (Mosk, J., dissent-

72. Such an imaginative construction is reminiscent of that in Diamond, where the court implicitly agreed that an insurance policy which seemed to require replacement in order for the insured to recover replacement value could in some circumstances be interpreted to permit recovery of replacement value without replacement. The construction is also similar to that in Murphy Slough, where a grant that appeared to be a fee simple was held to be an easement. See text accompanying notes 12-15, 23-25 supra. Such interpretations, however, could not fairly be achieved under a test of reasonable susceptibility on the face of the instrument. 
of the rules limiting constructive and inquiry notice may therefore be a useful source of analogy in determining the admissibility of extrinsic evidence.

A purchaser is not charged with constructive notice of every instrument previously recorded. An instrument must be within the purchaser's chain of title to impart constructive notice. ${ }^{73}$ The purchaser is not charged with notice of a conveyance from a person outside this chain $^{74}$ or of a conveyance from a person in the chain made before that person had record title. ${ }^{75}$ The common explanation for these limits is that it would be unreasonable to require that each purchaser conduct a search to uncover such conveyances. ${ }^{76}$

Inquiry notice is also limited by a criterion of reasonableness. The most common factual situation giving rise to inquiry notice is possession of the land being conveyed by a person other than the record owner. To charge the purchaser with the duty to investigate claims of the possessor, the possession must be "open, notorious and exclusive"77 and the possessor must be one whose presence is imcoinpatible with the record ownership. ${ }^{78}$ Likewise, when an instrument within the chain of title refers to another instrument, the purchaser is charged with notice of the contents of that instrument when a reasonably prudent person in the circumstances of the purchaser would have sought out the second instrument. ${ }^{79}$ When a purchaser has had previous dealings with the seller, the purchaser is charged with notice of circumstances reasonably revealed by the first transaction. ${ }^{80}$ Similarly, the purchaser cannot rely on the assurances of an interested party when the record raises a reasonable doubt as to the truth of the assurances. ${ }^{81}$ The coin-

73. In searching the chain of title, the purchaser must determine that neither the immediate grantor, that grantor's grantor, nor any more remote grantor made any conveyances inconsistent with the current record title while that person in the sequence held record title. Powell, supra note 1 , $\mathbb{1} 916$ (1977).

74. Bothin v. Califoruia Title Ins. \& Trust Co., 153 Cal. 718, 96 P. 500 (1908).

75. Ludy v. Zumwalt, 85 Cal. App. 119, 259 P. 52 (3d Dist. 1927).

76. Powell, supra note 1, $\$ 916$; Philbrick, Limits of Record Search and Therefore of Notice (pt. 1), 93 U. PA. L. REv. 125, 168-86 (1944) [hereinafter cited as Philbrick].

77. Pell v. McElroy, 36 Cal. 268 (1868); Evans v. Faught, 231 Cal. App. 2d 698, 42 Cal. Rptr. 133 (1st Dist. 1965). The application of the standard varies with the type of property involved. See, e.g., Natural Resources Inc. v. Wineberg, 349 F.2d 685 (9th Cir. 1965), cert. denied, 382 U.S. 1010 (1966).

78. Smith v. Yule, 31 Cal. 180 (1866), overruled on other grounds, Bell v. Pleasant, 145 Cal. 410, 414 (1904); Sanguinetti v. Rossen, 12 Cal. App. 623, 632-33, 107 P. 560, 564 (3d Dist. 1906). See generally Evans v. Faught, 231 Cal. App. 2d 698, 42 Cal. Rptr. 133 (1st Dist. 1965).

79. Renden v. Geneva Dev. Corp., 253 Cal. App. 2d 578, 61 Cal. Rprt. 463 (2d Dist. 1967).

80. Pellissier v. Title Guar. \& Trust Co., 208 Cal. 172, 280 P. 947 (1929).

81. Chalmers v. Raras, 200 Cal. App. 2d 682, 19 Cal. Rptr. 531 (1st Dist. 1962’, 
mon thread in these varied factual situations is that purchasers are charged with inquiry notice only when they have knowledge of facts that would have caused a reasonably prudent person to imquire further. ${ }^{82}$

\section{A Proposed Standard}

Simce the effect of using extrinsic evidence to interpret recorded conveyances is generally the same as charging the purchaser with inquiry or constructive notice of the interpretation, the admission of extrinsic evidence to interpret such instruments should be limited to the same extent as are imquiry and constructive notice. That is, a subsequent bona fide purchaser or encumbrancer of land ${ }^{83}$ should only be charged with notice of the interpretation of a conveyance which would be adopted by a reasonable person whose knowledge of the circumstances surrounding the conveyance is limited to that imparted by the documents in the purchaser's cham of title. Only if the court determines that the subsequent purchaser acted unreasonably in relying on one meaning should the result differ. Extrinsic evidence may then be introduced against the subsequent purchaser to establish the imterpretation intended by the original parties to the same extent that it may be used against those parties.

A reasonableness standard gives the courts the flexibility necessary in this area of widely differing factual circumstances. This flexibility contains a potential for abuse, however, because it allows the courts virtually unlimited discretion to tailor the rule of law to the facts of the case. ${ }^{84}$ The distortion permitted by such discretion when extrinsic evidence is involved is well illustrated by cases like Diamond and Murphy Slough. In order to shift the risks imherent in the application of such a fluid standard away from the subsequent purchaser, the courts should place the burden of persuasion on the issue of unreasonableness on the person seeking to introduce the extrinsic evidence. ${ }^{85}$

A standard based on the reasonably prudent person effectuates the basic purpose of the recording acts. The recording acts were intended to benefit subsequent purchasers, ${ }^{86}$ not to shelter the interests

82. PatTon, supra note $54, \$ 14$, at 74.

83. A bona fide successor is one who has given valuable consideration, who is not charged with actual or inquiry notice because of knowledge of facts outside the record, and whose instrument is recorded before the prior conveyance. See notes 50-55 supra.

84. The risks of such unlimited discretion are demonstrated by Manig v. Bachman, 127 Cal. App. 2d 216, 273 P.2d 596 (1st Dist. 1954); Three Sixty Five Club v. Shostak, 104 Cal. App. 2d 735, 232 P.2d 546 (1st Dist. 1951).

85. The formulation of the standard in terms of "unreasonable" rather than "reasonable" may also help shift the risks in close cases.

86. See note 51 supra and accompanying text. The policy of protecting subse- 
of prior grantees. ${ }^{87}$ To effectuate the intent of the legislature, the courts should not impose a greater burden on the purchaser than that already establislied by the rules of constructive and inquiry noticethe duty of acting as a reasonably prudent person in the circumstances. ${ }^{88}$

The proposed standard has the advantage of placing the risk of loss on the party most able to prevent it. Since the original parties are inore likely to enjoy access to information on the circumstances surrounding the conveyance, most interpretations based on extrinsic evidence will be asserted by a party to the original conveyance. The original parties control the drafting of the imstrument and therefore have an opportumity to express their intentions clearly at the outset. For example, if the parties in Beuhler had actually agreed that the easement could be used only to transport Garcia tract lumber, a simple modification could have avoided the entire controversy. ${ }^{89}$ Some failures in drafting may be inevitable. The subsequent purchaser, however, usually has more limited access to information concerning the original transaction and no control over its terms. Hence, it seeins fair to require that the original party accept the consequences of the original lack of precision.

quent purchasers is most prevalent in the field of real property transactions. Similar problems arise, however, where extrinsic evidence is introduced against a holder in due course of a negotiable instrument. See Copeland v. Stewart, 124 Cal. Rptr. 860, 862 63 (Court of Appeal, 1st Dist. 1975), nonpublication ordered by the supreme court, Dec. 17, 1975.

87. The interests of prior grantees were paramount at common law, under the rule of "first in time, first in right." The recording acts modified this principle to favor subsequent purchasers. Powel, supra note 1, T 912.

88. CAL. CTv. CODE $\$ 19$ (West 1954) defines constructive notice according to the standard of a reasonable person: "Every person who has actual notice of circumstances sufficient to put a prudent man upon inquiry as to a particular fact, has constructive notice of the fact itself in all cases in which, by prosecuting such inquiry, he might have learned such fact."

It might be argued that prohibiting the imtroduction of extrinsic evidence violates section 1860 of the Code of Civil Procedure, which provides that:

For the proper construction of an instrument, the circumstances under which it was made, including the situation of the subject of the instrument, and of the parties to it, may also be shown, so that the judge be placed in the position of those whose language he is to interpret.

Civil Code section 2925, however, seems to grant an exception to this rule for bona fide purchasers when the issue is whether an instrument that appears to be a deed was actually meant to be a mortgage. See text accompanying note 96 infra. Siuce the policies behind the recording acts are the same with respect to all unexpected interpretations, it seems reasonable to imply a broader exception in favor of subsequent purchasers. At any rate, section 1860 can be construed to require the imtroduction of extrinsic evidence only when the instrument is ambiguous on its face. See CaL. CIv. Code $\$$ 1638-40 (West 1956).

89. The drafters could easily have limited the use of the easement to any purposes reasonably related to the ownership, management and exploitation of timber and forest products taken from lands within the Garcia tract which from time to tine might be owned or controlled by the holders of the easement. 
The proposed standard is also supported by the strong public policy in favor of certainty in land titles. ${ }^{90}$ Commentators who support the use of extrinsic evidence in interpretation assert that its exclusion fails to increase the certainty of written instruments..$^{91}$ This failure, however, appears to be less a result of the rule itself than of the numerous exceptions to the rule carved out by courts attempting to balance the equities in specific cases. ${ }^{92}$ Relying only upon the written instrument and the record eliminates some of the uncertainty which is necessarily introduced by the use of extrinsic evidence. For example, the parties can never be certain what extrinsic evidence will be available in the event of litigation-witnesses die and memories fade. The demeanor of a witness can never be predicted but it may significantly affect the weight given the testimony. These variables can be avoided and greater certainty achieved if the courts recognize the strong equity in favor of bona fide purchasers mandated by the recording acts and consistently exclude extrinsic evidence that does not meet the proposed standard.

Professor Corbin has argued that a standard that relies on the face of the instrument is impossible to apply: "[N] man can determine the meaming of written words merely by glueing his eyes within the four corners of a square paper ... it is men who give meanings to words . . . words themselves have no meaning." "93 This argument, however, runs contrary to the entire basis of the recording acts. These acts rest on a legislative judgment that the vast majority of written instruments in the public record do in fact express the intent of the drafters with sufficient precision to protect the interests of both original parties and subsequent purchasers. Moreover, when further context is required, it can usually be supplied by referring to other documents in the chain of title.

Adoption of this approach does not require an abrupt departure from traditional principles of law. The Beuhler court recognized the standard in principle though not in application, ${ }^{94}$ and at least two other states have adopted similar rules. ${ }^{95}$ The Civil Code itself suggests that

90. See Riley v. Bear Creek Planning Comm., 17 Cal. 3d 500, 510, 551 P.2d 1213, 1220, 131 Cal. Rptr. 381, 388 (1976); McBride v. Freeman, 191 Cal. 152, 215 P. 678 (1923).

91. WIGMORE, supra note 4, $\$ 2462$, at 192; Comment, Parol Evidence, supra note 49, at 949 .

92. See Morgan, supra note 5, at 414; Comment, Parol Evidence, supra note 49, at $950-51$.

93. Corbin, The Interpretation of Words and the Parol Evidence Rule, 50 CoRNELL L.Q. 161, 164 (1965).

94. See note 68 supra and accompanying text.

95. Hudson \& Collins v. McGuire, $188 \mathrm{Ky} .712,223$ S.W. 1101 (1920); Weniger v. Ripley, 134 Ore. 265,293 P. 425 (1930). 
in some circumstances subsequent purchasers in good faith should be subject to a different standard of interpretation than are the parties to the contract. Civil Code section 2925 provides that an instrument cast in the form of a deed, but actually intended by the parties to operate as a mortgage, may be proved to be a inortgage "except as against a subsequent purchaser or encumbrancer for value and without notice."9o Bona-fide purchasers are given protection against interpretations they would not expect while parties to the conveyance are not similarly protected.

In contrast, recent marketable title legislation adopted in other states permits much inore drastic departures from the policy of effecting the intention of the parties, in order to achieve a more reliable record. ${ }^{97}$ These statutes attempt to provide the purchaser with a more certain title by clearing potential adverse claims from the record. Typically, they provide that claims not asserted after a certain number of years are extinguished. ${ }^{98}$ The proposed standard resolves a different aspect of the problein of uncertainty; it does so with less violence to traditional primciples of law.

\section{IV}

\section{Extrinsic Evidence and Real Property INSTRUMENTS RECONSIDERED}

The proposed standard provides for an exception to the $P G \& E$ rule for imstruments conveying interests in real property only when the interests of a person explicitly entitled to the protection of the recording acts will be affected. The pohicies behind the recording acts and the need to give effective protection to bona fide purchasers may, however, require a more sweeping exception.

\section{A. Other Third Parties}

Although the protection of subsequent purchasers is cited most of-

96. CAI. CIv. CODE $\$ 2925$ (West 1954); cf. id. $\$ 2950$ (providing that when a grant is intended to be defeasible on certain conditions the defeasance is not effective against persons without notice unless it is recorded).

97. E.g., FLA. STAT. ANN. $\$ \$ 712.01-10$ (West 1969 \& Supp. 1976); IOWA CODE ANN. $\$ \$ 614.17-.20$ (West 1950 \& Supp. 1976); Mich. CoMp. LAws ANN. \$§ 565.101.109 (1967); OHIo Rev. Code ANN. $\S 5301.47-.56$ (Page 1970 \& Supp. 1977). Marketable title laws provide that if a person has a record chain of title for a specified period of time, usually 40 years, and no one else has filed a notice of a claim to the property during this period, then all conflicting claims based on transactions prior to the 40 year period are extinguished. L. Simes \& C. TAYLOR, THE IMPROVEMENT OF CONVEXancing BX LegisLation 4 (1960).

98. One commentator has suggested that marketable title legislation may in fact diminish the protection now given to bona fide purchasers. Barnett, Marketable Title Acts-Panacea or Pandemonium? 53 Cornell L. Rev. 45 (1967). 
ten as the policy behind the recording acts, ${ }^{99}$ another, perhaps more basic, purpose of the acts is to publicize conveyances of real property for the benefit of the entire public. The preamble of the 1640 Massachusetts Bay statute, one of the earliest recording statutes in the American colonies, gave as its purposes: "For avoyding [sic] fraudulent conveyances, and that every man may know what estate or interest other nien liave."100 The earliest forerunner of recording statutes, the Statute of Enrollments, ${ }^{101}$ was clearly intended to replace feoffinent as a means of publicizing conveyances in land. ${ }^{102}$ Most commentators have agreed that publicizing land conveyances is among the purposes of niodern recording acts. ${ }^{103}$ The form of the California statute buttresses the assertion of this purpose. To be protected under Civil Code section 1214, purchasers nuust not only take without knowledge and pay a valuable consideration but nust also record their own conveyances before prior imstruments are recorded. ${ }^{104}$ This statutory requirement of prior recordation is not necessary to achieve the purpose of protecting the current purchaser froin prior conveyances. Neither is it needed to safeguard later purchasers. Even under a pure notice statute, a purchaser is not affected by any prior unrecorded conveyance. The requirement of prior recordation has the effect of denying protection against prior conveyances to a purchaser who does not record. It thus encourages publication as a good independent of the protection of subsequent purchasers.

Insofar as the recording statutes embody a general policy in favor of publicizing conveyances of land, the introduction of extrinsic evidence to interpret recorded conveyances undermines that goal. ${ }^{105}$ The use of extrinsic evidence for interpretation permits the parties to the conveyance to enjoy some or perhaps all of the benefits of recordation

99. See authorities cited in note 51 supra.

100. Powell, supra note $1, \Uparrow 912$ (quoting 1 Massachusetts Records at 306).

101. 1536, 27 Hen. 8, c. 16.

102. PatTon, supra note $56, \S 3$, at 6 . Current recording acts differ from the Statute of Enrollments in that the Statute required enrollinent, the approxinate equivalent of recording, to validate the conveyance as between the original parties.

103. Patton, supra note 54, \& 6, at 15; Johnson, Purpose and Scope of Recording Statutes, 47 Iowa L. Rev. 231, 231 (1962); Philbrick, supra note 76, at 131, 146-49.

104. Recording statutes are of three basic types. Race statutes require only that a subsequent purchaser first record; the purchaser's knowledge of prior conveyances is irrelevant. Notice statutes do not require prior recording; protection hinges on the purchaser's lack of notice of prior conveyances. California's statute is of the race-notice type. It requires both prior recording and lack of notice. Johnson, supra note 103, at 231-33.

105. This analysis does not extend to unrecorded conveyances, siuce the statute does not require recording of conveyances to make them valid between the original parties and does not protect third parties other than subsequent purchasers against unrecorded couveyances. 
without meeting the full disclosure standards of the acts. ${ }^{106}$ The decision of whether the policy of publicity or that of effecting the intent of the parties should control is affected by whose rights are being litigated.

Third parties who are not bona fide purchasers may have a considerable interest in the interpretation of a conveyance. In Murphy Slough, for example, the plaintiffs were owners of property downstream froin that affected by the instrument being interpreted. ${ }^{107}$ Whether the writing had conveyed a fee or merely an easeinent might have affected the downstream owners' rights to water. ${ }^{108}$ Similarly, the holder of property adjacent to that which is benefitted by an easeinent for light and air may be vitally interested in the scope of his neighbor's easement. ${ }^{109}$ In such cases, the policy of affording the public access to accurate records is directly undercut by the admission of extrinsic evidence to give an instrument an interpretation to which it would otherwise not be reasonably susceptible. Additionally, if extrinsic evidence is admitted, the third party is likely to be disadvantaged by a lack of personal knowledge of the circumstances surrounding the conveyance. Thus when the rights of any third parties who can prove actual rehiance are directly involved in the hitigation, the rule proposed for bona fide purchasers should govern.

Proof of actual reliance imiposes a substantial burden on third parties seeking this protection. The complaiming party must demonstrate that it acted upon the written record, and would not have so acted had it known of the extrinsic evidence. Such a burden is necessary to prevent third parties without substantial interests in the transaction from litigating the property rights of other persons. In the case of bona fide purchasers, actual reliance should be presuned because the purchaser's own property rights will be directly affected.

\section{B. The Original Parties}

When only the rights of the parties to the original conveyance are involved, the policies at stake are quite different. Persons who would

106. The original parties benefit from recordation by being protected against.subsequent purchasers at least as to provisions where the agreemeut accurately reflects their intentions and, if Beuhler is followed, even as to their undisclosed intentions.

107. 27 Cal. App. 3d 649, 104 Cal. Rptr. 136 (1972), discussed iu text accompanying notes 22-26 supra.

108. As an alternate basis for its decision in Murphy Slough, the court ruled that even had the conveyance granted a fee, the grant would not have had any different effect on riparian rights. $27 \mathrm{Cal}$. App. 3d at 658, $104 \mathrm{Cal}$. Rptr. at 143-44.

109. The most frequent interested third parties not protected by the recording acts will be subsequent purchasers who have failed to record. These persons, however, should probably not be extended this protection based on the publication policy, because their failure to record directly undercuts the publication goal. 
have benefitted from an accurate record will seldom be directly harmed by the use of extrinsic evidence. Theoretically access to evidence on the circumstances surrounding the conveyance should be equal. Thus the $P G \& E$ rule seems appropriate.

Permitting the use of extrinsic evidence even between the contracting parties to give an instrument an interpretation to which it is not reasonably susceptible on its face will, however, indirectly diminish the protection given to bona fide purchasers and other third parties. The proposed standard protects third parties only when they are not charged with notice of the asserted interpretation due to their knowledge of facts outside of the record. When third parties have such inquiry notice, extrinsic evidence may be used against them as it is used against parties to the conveyance. ${ }^{110}$ Differing standards of admissibility for third persons and original parties place a tremendous burden on the definition of mquiry notice, the standard that distinguishes one from the other. Because the current inquiry notice standard is based on the inherently flexible concept of reasonableness, it is easily abused. ${ }^{111}$ As it is presently applied, it is an inadequate foundation for the important protection afforded third persons, and especially to bona fide purchasers under the recording acts.

The tension between the desire to permit the use of extrinsic evidence to give full rem to the intention of the original parties and the need to avoid indirect diminution of the rights of third parties can be resolved without forfeiting either important goal. Tightening the aplication of the inquiry notice standard will permit the use of two different standards and provide a clear distinction between the situations where each is appropriate. The courts must remember that the recording acts were meant to protect bona fide purchasers and, as has been argued, other third persons. The strong statutorily imposed equity in their favor must be weighted along with the equities in the individual case and doubts called in favor of the third parties. If this protection is given to third parties, then it is reasonable to allow the use of extrinsic evidence under the $P G \& E$ rule in interpreting property instruments when only the original parties or persons reasonably charged with inquiry notice of the imstruinent's interpretation are involved.

\section{CONCLUSION}

The modern trend of generally adıitting extrinsic evidence is not an unqualified inprovement over the formahsm of the coinunon law. While it serves the important purpose of effectuating the intentions

110. See section III.D supra.

111. See note 84 supra and accompanying text. 
of the parties, when applied in the realm of real property, it may violate equally important policies. Since the recording acts evidence strong legislative support for the policies of public access to title records and protection of subsequent purchasers of land, these competing goals must be carefully balanced. In situations where only the riglits of original parties or third persons who failed to rely on the public record are at stake, the policies underlying the recording acts are only indirectly threatened. The policy of implementing the imtentions of the original parties to the contract is therefore persuasive and the extrinsic evidence should be admitted. Where, however, the interests of bona fide purchasers or other third persons who actually relied on the record may be affected, the goals of protection and publicity are directly jeopardized by the introduction of extrinsic evidence. In such cases, extrinsic evidence should be adinitted only when a reasonable person would find the written record ambiguous.

Linda Little Carloni*

* B.A. 1975, Case Western Reserve University; third-year student, Boalt Hall School of Law; Executive Editor, California Law Review. 


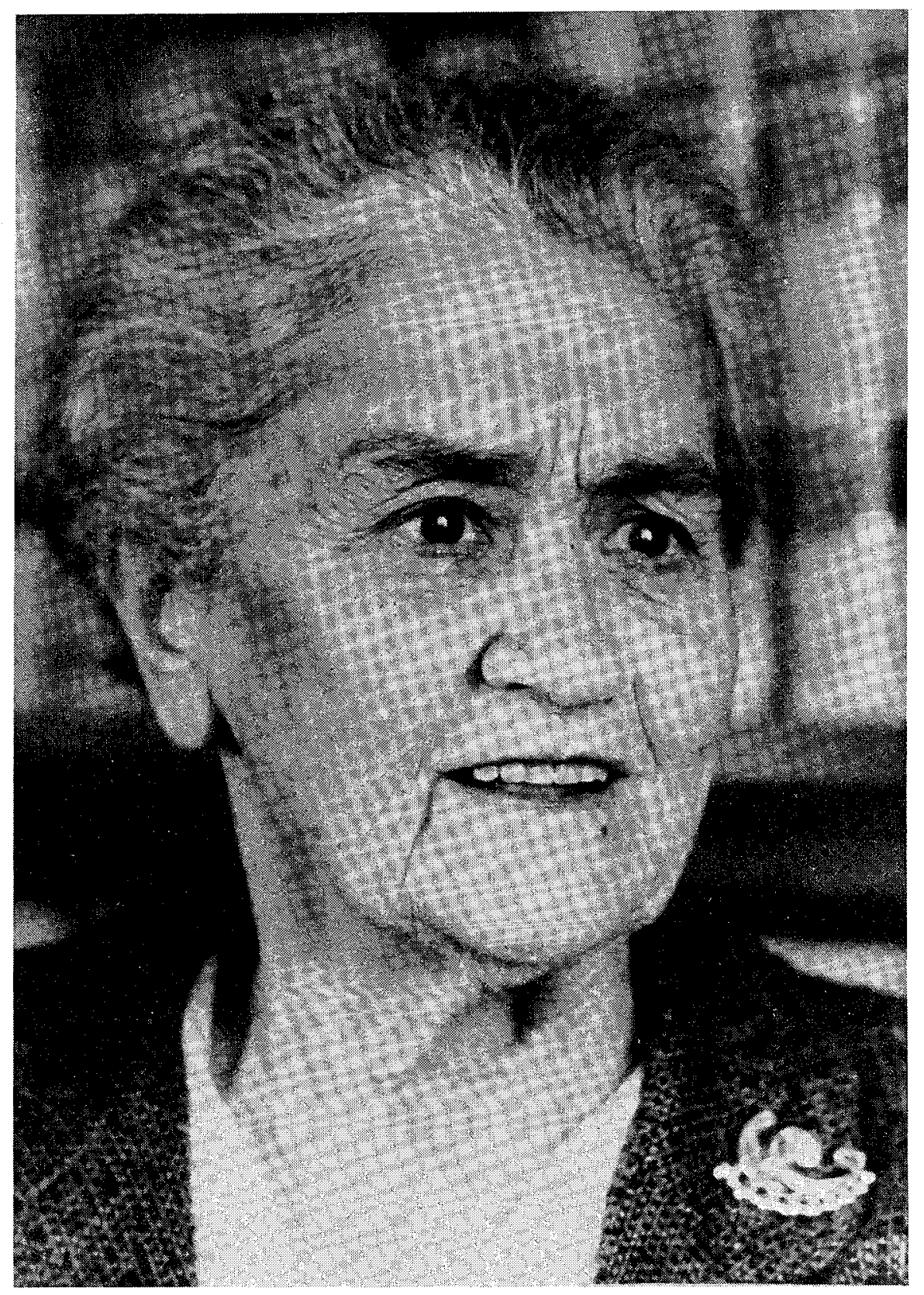

BARBARA NACHTRIEB ARMSTRONG 


\section{California Law Review}

\begin{tabular}{lll}
\hline \hline VoL. 65 & SEPTEMBER 1977 & No. 5 \\
\hline
\end{tabular}

Copyright (C) 1977 by California Law Review, Inc.

\section{IN MEMORIAM}

Barbara Nachtrieb ARMSTRong

Roger J. Traynor

920

Adrian A. Kragen, Herma Hill Kay

\& Stefan A. Riesenfeld 927

Sam Kagel 929

Richard C. Dinkelspiel 932

Kathryn Gehrels 933

\section{ARTICLES}

Marvin v. Marvin:

Preserving THE OPTIONS

Herma Hill Kay

937

\& Carol Amyx

Progress UNder THE UNIForm ChILd CUSTOdY

JURISDICTION ACT AND REMAININg PROBlems:

Punitive Decrees, Joint Custody,

AND EXCESSIVE MODIFICATIONS

Brigitte $M$. Bodenheimer

978

The Legal Import of INFormal Marital

Separations: A SuRvey of California

Law and a Call for Change

Carol S. Bruch 1015

\section{COMIMENTS}

Equal Rights Provisions: The EXPertence

Under State Constitutions

Lujuana Wolfe Treadwell 1086 \& Nancy Wallace Page

EMPLOYMENT RIGHTS OF WOMEN

IN THE TOXIC WORKPLACE

Joan I. Samuelson 1113 


\title{
DEDICATION
}

\begin{abstract}
Aluma of the University In the Class of 1913, AND Morrison Professor of Municipal LaW, EMERITUS; DistiNGUISHED BY THE BREADTH AND DEPTH OF YOUR TEACHING AND RESEARCH IN LAW AND ECONOMICS; FORMER EXECUTIVE SECRETARY OF the California Social Insurance CoMmission, with A SUSTAINED INTEREST IN THE LAW AFFECTING THE MORE DEPENDENT SECTIONS OF THE COMMUNITY; AN AUTHORITY ON FAMILY LAW AND COMMUNITY PROPERTY; AUTHOR OF A MONUMENTAL TEXT IN THIS FIELD; ACUTE, DISCERNING, ARTICULATE WHEN COMMON SENSE NEEDS EXPRESSION, YOU HAVE WON THE RESPECT AND AFFECTION OF YOUR COLLEAGUES AND YOUR STUDENTS. FOR YOUR KNOWLEDGEABLE CONCERN WITH SOCIAL LEGISLATION, FOR THE HIGH QUALITY OF YOUR SCHOLARSHIP; AND FOR SELFLESS SERVICE TO THIS INSTITUTION AND PARTICULARLY TO ITS STUDENTS, YOUR UNIVERSITY SALUTES YOU TODAY.
\end{abstract}

-Inscription on the honorary doctor of laws degree conferred upon Professor Armstrong by the University of California, June 10, 1961.

The legal profession has changed greatly since Barbara Armstrong entered law school some sixty-five years ago. While Ms. Armstrong was the only female in the Class of 1915, women today occupy two out of five seats in Boalt Hall. Had she lived another year, Professor Armstrong, the first woman law professor in the United States, would have seen a woman become Chief Justice of the California Supreme Court. The time finally approaches when women's achievement of such status shall be accepted as customary.

In Professor Armstrong's memory, we have assembled a collection of articles by women legal scholars and law students. The Articles in this issue explore developments in family law, the field dominated by Barbara Armstrong's work. The Comments deal with topics of interest in the area of women's rights, a subject that pioneer professional women such as Professor Armstrong helped to make possible. Finally, the late Professor is remembered by representatives of several sectors of the legal profession: scholastics, practitioners, and jurists-her students, her colleagues, and her friends.

The California Law Review proudly dedicates this issue to the living memory of Barbara Nachtrieb Armstrong.

The Board of Editors 